\title{
The influence of trust, satisfaction, value, and brand image on loyalty
}

\author{
Gandadinata Thamrin $^{1^{*}}$, Innocentius Bernarto ${ }^{2}$, and Yukichika Kawata ${ }^{3}$ \\ ${ }^{1}$ Faculty of Economics and Business, Pelita Harapan University \\ Jalan M.H Thamrin Blvd 1100, Lippo Karawaci, Tangerang, Banten15811,Indonesia \\ gandadinata.thamrin@uph.edu \\ ${ }^{2}$ Faculty of Economics and Business, Pelita Harapan University \\ Jalan M.H Thamrin Blvd 1100, Lippo Karawaci, Tangerang, Banten15811,Indonesia \\ innocentius.bernarto@uph.edu \\ ${ }^{3}$ Faculty of Economics, Kindai University \\ 4-1 Kowakae 3-chome, Higashiosaka 577-8502, Japan \\ ykawata@kindai.ac.jp
}

\begin{abstract}
This study aims to investigate the influence of trust, satisfaction, values, and brand image on the loyalty of MaxxCoffee. Data collection in this study was conducted using a questionnaire given to students of Universitas Pelita Harapan as respondents. The research design uses convenience sampling with a total sample of 249 samples. The data collection method is utilizing questionnaires and the data is analyzed by the Partial Least Square of Structural Equation Modeling (PLS-SEM). The findings of this study are trust, satisfaction, and value have a positive effect on loyalty. Conversely, the brand image has no positive effect on Maxx Coffee customers' loyalty. The contribution of this study is providing input to the management of Maxx Coffee to concern and maintain their trust, satisfaction, value, and brand image of Maxx Coffee to maintain the customers' loyalty.
\end{abstract}

Keywords: brand image; loyalty; satisfaction; trust; value.

Received: August 7, 2019; Accepted: February 10, 2020; Published: April 28, 2020

*Corresponding author

Email:gandadinata.thamrin@uph.edu

How to cite this document:

Thamrin, G., Bernarto, I., \& Kawata, Y. (2020). The influence of trust, satisfaction, value, and brand image on loyalty.BISMA (Bisnis dan Manajemen), 12(April), 168-185. https://doi.org/10.26740/bisma.v12n2.p168-185 
Page168-185

\begin{abstract}
Abstrak
Penelitian ini bertujuan untuk mengetahui pengaruh kepercayaan pelanggan, kepuasan pelanggan, nilai-nilai dan citra merek terhadap loyalitas pelanggan Maxx Coffee. Pengumpulan data dalam penelitian ini dilakukan dengan menggunakan kuesioner yang diberikan kepada mahasiswa Universitas Pelita Harapan sebagai responden. Desain penelitian menggunakan convenience sampling dengan total sampel 249 sampel. Metode pengumpulan data menggunakan kuesioner dan data dianalisis dengan Partial Least Square dari Structural Equation Modeling(PLS-SEM). Temuan penelitian ini adalah kepercayaan pelanggan, kepuasan, dan nilai berpengaruh positif terhadap loyalitas. Sebaliknya, citra merek tidak berpengaruh positif terhadap loyalitas pelanggan Maxx Coffee. Kontribusi dari penelitian ini adalah memberikan masukan kepada manajemen Maxx Coffee untuk memperhatikan dan mempertahankan kepercayaan, kepuasan, nilai dan citra merek mereka dari Maxx Coffee untuk menjaga loyalitas pelanggan.
\end{abstract}

Kata kunci:citra merek; kepercayaan; kepuasan; loyalitas; nilai.

\title{
INTRODUCTION
}

Today the growth of the coffee industry in Indonesia is increasing along with changes in the lifestyle of the Indonesian people, especially the middle class. According to the Indonesian Coffee Exporters Association, Indonesian demand for coffee consumption continues to rise and coffee demand rises by $36 \%$ from 2010 to 2014 (Rikang \&Dharma, 2014). Indonesia's coffee consumption is 800 grams per capita and Indonesia's total coffee demand reach 190 thousand tons (2010) and continues to rise until the end of 2014, about 1.03 kilograms per capita with total coffee demand about 260 thousand tons (Menperin, 2016).

Indonesia is the fourth largest coffee producer in the world (after Colombia, Vietnam, and Brazil) with an average coffee production of 685,000 tons per year or $8.9 \%$ of world coffee production. The Ministry of Industry has facilitated the pace of the coffee processing industry in Indonesia and the growth of coffee shops or coffee shops in Indonesia under PP No. 14 of 2015 about the Development Master Plan of National Industry 2015-2035 and PP No. 18 of 2015 about income tax-shield facilities. Therefore, under this supportive business climate, Maxx Coffee was established in 2015 and started to sell its local coffee beans with international flavors but with affordable prices for its customers. In 2016, their outlets have expanded to various cities in Indonesia, such as UPH Karawaci, and even they planned to open more than 80 outlets across Indonesia (Jelemone, 2015).

Basedon an interview with the Maxx Coffee manager, it was revealed that $60 \%$ of UPH students were expected to buy Maxx Coffee products about 2-3 times a week. The initial research also showed that around $60 \%$ of UPH students buy Maxx Coffee products, although only once a week. Thus, there are differences in company expectations with facts on the ground. Furthermore, to overcome this problem, it is important to increase UPH student loyalty as the expectations of managers by concern on the customer values, trust, satisfaction, and brand image 
of Maxx Coffee.

The purpose of this study is to determine whether trust, satisfaction, value and brand image have a positive effect on Macc Coffee customer loyalty. The results of this study can provide insight to Maxx Coffee's management to increase customer loyalty and ultimately increase total revenue as well.

\section{Loyalty}

With current technological advances, customers are increasingly smart, aware of the price and quality of the products they want. There are a lot of product offers with accessible and abundant information about them that enable the customers to have many choices in determining which products and services they want(Bowden-Everson, Dagger, \& Elliott, 2013). With these choices, customers determine their loyalty to certain products routinely and continuously at certain periods even though other products provide lower prices (Bowden-Everson et al., 2013). According to Griffin (2003), loyalty is closely related to the purchase cycle (buying behavior) which goes through five stages: (1) Customer awareness of products and services, (2) Initial purchase, (3) Evaluation after purchase, (4) Customer decision to repurchase the product, and (5) Repeated purchase (Gultom \& Ngatno, 2020). Therefore, loyal customers are customers who make repeated purchases regularly, buy between product lines and services, recommend products and services to other consumers, and show immunity to what is offered from competitors (Kinanti \& Fauzi 2020). As a result, retaining customers means increasing company performance.

Based on the previous description, Oliver (1999, p. 34) stated that "a deeply held commitment to rebuy or repatronize a preferred product/service consistently in the future, thereby causing repetitive same-brand or same brand-set purchasing, despite situational influences and marketing efforts having the potential to cause switching behavior". In the research of Mandalis (2005), it is explained that loyalty is built with two approaches in customer repurchase behavior such as customer preference for the product bought (attitude approach) and customer behavior which customer only buy a product repeatedly without their feeling. Meanwhile, customer loyalty is developed through three stages, namely cognitive, affective, and conative stages where the customer will be loyal first through thecognitive aspect; then develops to become more loyal through affective aspect and finally to become the true loyalist through conative aspect. This is in line with the consumer behavior science that consumers usually will pass three stages of learning: perception, attitude and behavior (Darsono, 2010; Herawati, Widodo, Isman, \& Darham(2019).

\section{The Relationship of Trust on Loyalty}

Anderson and Weitz (1989) stated that trust is a level of belief that is owned by a person towards others which other people's beliefs will apply the same as 
expected by that person. It can be said that brand trust is an important basis in building successful marketing relationships where customers have a high level of confidence in the reliability and integrity of the company and its products (Chinomona \& Dubihlela, 2014; Morgan \& Hunt, 1994).

Brand trust shows the ability of a brand to be trusted and meets the value promised by the company to the customer and increases brand intention based on consumer confidence inthe brand. This means that the customer confidence towards the benefit they might gain in buying can build their satisfaction and loyalty (Sovani, Fauzi, and Arifin, 2016).In Hasanuddin, Rachma, and Wahono (2020) that investigated the consumer behavior of Mr. Beard Coffee, trust also shows a positive and significant influence on customer loyalty.

Soegoto (2013) explains that the relationship between trust and emotional bonding was built when customers entrust the company's or brand's ability to carry out its functions. The existence of consumer expectations for product benefit will create loyalty and brand trust. Morgant and Hunt (1994) stated that trust arises when there is an exchange between two parties in which one party believes the other party has integrity and reliability. Kotler and Keller (2012) explained that the costumer compare the performance of the product with their expectations as post purchase evaluation. At this stage, the costumers is disappointed when the product's performance is below their expectations; feel satisfied when product's performance equals to their expectations; costumers feel delighted when product's performance exceeds their expectations.

Meanwhile, Setyaningsih (2014) explained that the effect of perceived ecommerce service quality on customer satisfaction, trust, and loyalty in fashion products, proved that trust has a significant effect in increasing customer loyalty. The research results of Puspita,Yunus, and Sulaiman(2017) shows that trust influences positively on loyalty in the case study of Samsung users at Banda Aceh city. Furthermore, the study of Darsono (2010) and Muzammil,Yunus, \& Darsono (2017) revealed that customer trust had a significant and positive effect on Indihome's customer loyalty in Banda Aceh city. Hence, based on the previous studies above, the researchers formulated the hypothesis as follows:

H1: Trust has a positive effect on loyalty.

\section{The Relationship of Satisfaction on Loyalty}

Most managers agree that there is a positive correlation between customer buying behavior and the results of the customer satisfaction score.The general assumption is that an increase in a customer's satisfaction score will be followed by an increase in the share of income spent by the customer, the company's reference level from the other party (rate of referral) and customer willingness to pay at a higher price (premium price) (Griffin 2003, p. 3). Lamb, Hair, and Daniel 
(2005) explained that customer satisfaction is the fulfillment of customer expectations of a product. Consumer satisfaction is important that have a specific benefit impact to maintain products in the market as well as to gain wider market share so that the company can increase its profits (Chinomona \& Sandada. 2013; Listyawati, 2019; Muzammil,Yunus, \& Darsono, 2017; Setyaningsih, 2014).

According to Rangkuti (2004), companies need to know, understand, and measure customer satisfaction for fulfilling customer expectations, customer relationships, customer referrals, and customer recovery. Customer satisfaction means the customer's response to the evaluation of perceived discrepancies between the actual performance of the product felt and customer expectations; customer satisfaction is an emotional reaction to customer evaluation of the experience of products or services (Farida, 2010; Laila, Rachma, \& Priyono (2017). Meanwhile, Irawan (2003) said there are at least three reasons why companies need to measure their customer satisfaction: increasing competitiveness, more and more companies which increase their costs, investments, and resources to prioritize customer satisfaction programs and put it as a measurement of company goal achievement and performance, and changes in customer expectations from time to time that encourages companies to conduct research and make decisions for the future.

Moreover, Gerson (2004) stated that customer satisfaction is customers satisfying feeling if their expectations can be met, even exceeding their expectations. Every time, a customer evaluates the quality of service and goods, and how their satisfaction has influenced their loyalty. Customer satisfaction affects customer buying behavior. If customer satisfaction is high toward products or services, they will become loyal customers for those products or services.

A research conducted by Kurniawati, Suharyono, \& Kusumawati (2014) and Tjahjaningsih (2013) show that customer satisfaction gives a positive value to loyalty. The creation of a harmonious relationship between customers and companies will make repeat purchases and create customer loyalty and word of mouth promotion that gives benefit to the company. Hence, it can be concluded that customer satisfaction is built from customer experience when using the product that influences customer loyalty, repeat purchases, and recommendation of products to other customers. This is also reinforced by research from Bernarto and Patricia (2017) that customer satisfaction has a positive effect on customer loyalty and trust. Thus, this study hypothesizes that:

H2: Satisfaction has a positive effect on loyalty.

\section{The Relationship of Value and Loyalty}

Yoeti (2005) explains that company customers are potential customers who buy goods and services that can satisfy their needs by paying attention to the value they will receive. Kotler and Armstrong (2008) explain that marketing is a 
managerial and social process in which individuals or organizations get what they need and want through the means of exchange and value creation with others. A company's value is an overall customer evaluation of the usefulness of the product or service based on the assumption of what is obtained and given by the customer (Bernarto \& Patricia, 2017).

Soegoto (2013) added that the terminal, instruments, or goals and objectives where the behavior achieved by the company is a valuable company value. The effect of the relationship between value and loyalty is the customer's experience in interacting with several objects giving characteristics that appear in relative preferences (personal, comparative, and situational) where the value obtained by the customer is higher the customer gives loyalty and profits to the company (Barnes,2000; Gale, 2004). The research of Bernarto and Patricia (2017) and Soegoto (2013) stated that if the customer's perception about the value of a quality product is relatively higher than that of a competitor's product, it will increase the level of customer loyalty, as well as the higher value perception of the customer, the greater the possibility of repeat purchase. This shows the relationship between value and customer loyalty. Hence, this study hypothesizes that:

H3: Value has a positive effect on loyalty.

\section{The Relationship of Brand Image on Loyalty}

Kotler (2000) stated that a brand is the benefits, features, and certain services that the company promises to customers consistently and continuously. This is not merely a product symbol or a product characteristic that distinguishes it from competitors' products. Keller (1993) stressed that brand awareness might be remembered in the minds of customers, while the brand association is the assumption of a brand of products held in consumers' memories.

According to Simamora (2002), brand image is a collection of associations such as names, signs, symbols, designs or combinations that created or maintained by companies to give identity, and differentiation the goods or services with other products and to support the existence of entities company identifiers that have certainly added value. The company provides the symbols, characteristics, and indicators of the quality of its products and the brand that survives will continue to be remembered by its customers into an image or status symbol of the wearer. Customers not only buy company products because of their functional benefits but also buy their symbolic value as emotional value and the value of the customer's self-expression when using the product. This symbolic value is called a brand image that contains the symbol, identity, or personality attached to the product. $\underline{\text { Scoot (2000) }}$ stated that the association of brands consists of attributes and features, values and beliefs, and benefits. Features and attributes are the basic factors that every brand must fulfill before stepping on providing benefits or 
values or beliefs because the quality of products, services, and sources of human power (attributes and features) determine the success of the brand.

Pramudyo (2012) explained that customer satisfaction and loyalty depend on the role of brand image in increasing consumers' perceptions and expectations about the goods or services offered. Furthermore, the repurchase decision is significantly influenced by the company's image and customers prefer to avoid risk and have a better product brand image. On the other hand, customers will be helped by a good brand image of a product when customers make purchasing decisions and transactions which have a positive influence and makes consumers loyal to the product. Thus, in this study, we hypothesize as stated in H4. The framework for thinking of this study is linking the role of the construct of trust, satisfaction, values, and brand image to loyaltyas shown in Figure 1.

H4: Brand image has a positive effect on loyalty.

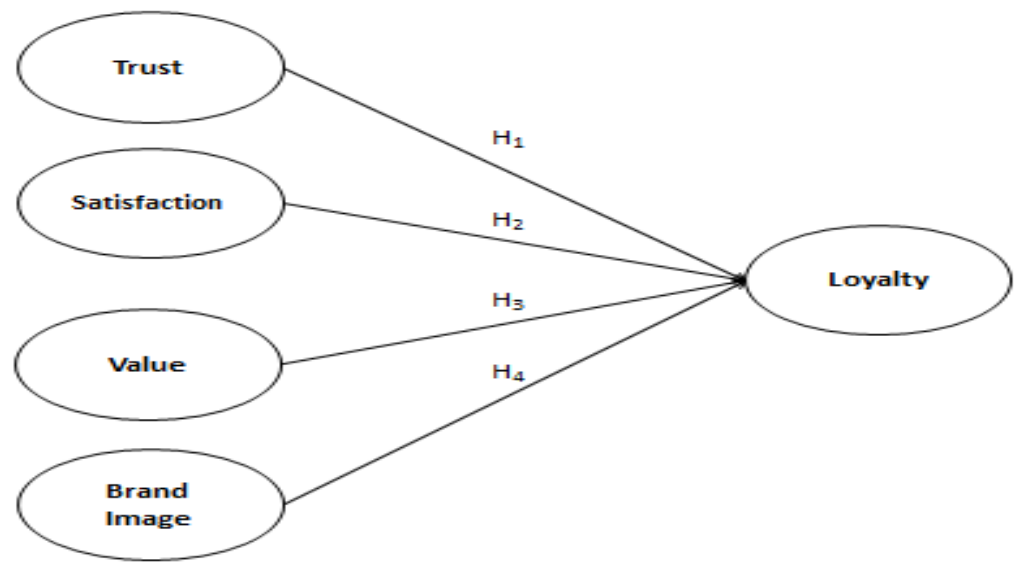

Figure 1. Research Framework

\section{METHODS}

The research method uses quantitative methods by testing the correlation of the hypothesis model (Bernarto and Patricia, 2017). The data obtained were processed by the PLS-SEM statistical program to observe the causality of the construct at a certain time and not on changes at a certain period.

\section{Data Collection and Sampling}

This research model connects the role of trust, satisfaction, value, and brand image to the loyalty of Maxx Coffee customers. In this case, the researchers conducted a survey and questionnaire to the target population in this study, namely students majoring in management, majoring in hotel management and tourism businesses, and UPH medical staff who visited Maxx Coffee. Maxx Coffee was established in the university environment in Karawaci, Banten, Indonesia. The sampling technique is convenience sampling which the number of samples or respondents is 249 respondents. Profile of respondents obtained from 249 
respondents who filled out the questionnaire distributed, where the results were 80 respondents who participated were men and 169 respondents were women. The age range of respondents is divided into three categories: 17-19 years (117 people), 2022 years (128 people), and 23-25 years (4 people). Meanwhile, most respondents visit the shop about 1-2 times per month (80\%) and $89 \%$ did not come to Maxx Coffee for the first time in UPH, most respondents visited the last 3 weeks (65\%), most came in morning (58\%), and choose to come with friends $(81.9 \%)$ with the main reason for the visiting coffee shop is doing the work and gathering with friends. The complete information about the profile of respondents can be seen in table 1 .

\section{Data Analysis and Hypothesis Testing Techniques}

\begin{tabular}{lc}
\multicolumn{1}{c}{ Category } & Respondent (Percentage) \\
\hline Gender: & 32 \\
Male & 68 \\
Female & \\
Age: & 47 \\
$17-19$ & 51 \\
$20-22$ & 2 \\
$23-25$ & \\
Visit per month: & 80 \\
$1-2$ times & 12 \\
3-4 times & 8 \\
More than 4 times & \\
Visit time: & 4 \\
Breakfast time & 58 \\
Lunch time & 27 \\
Supper time & 11 \\
Dinner time & \\
Visit with: & 13 \\
Alone & 3 \\
Couple & 82 \\
Friends/Colleagues & 2 \\
Family & \\
Visit purpose: & 14 \\
Eating/Drinking & 6 \\
Hangout with friends & 36 \\
Enjoying private leisure time & \\
Doing assignment &
\end{tabular}

Source: Data Processed

The research method uses a statistical tool Partial Least Square Structure Equation Modeling (PLS-SEM) with the Smart PLS 3.0 program (Ghozali \& Latan, 2015). Questionnaire items in the Trust construct were adapted from $\mathrm{He}, \mathrm{Li}$, and Harris (2012); Pi and Huang (2011); Shpetim (2012). The items of satisfaction construct were adapted from Shpetim (2012). The items of trust construct were adapted from He et al. (2012); Yang and Peterson (2004). Meanwhile, the items for 
brand images were adapted from Kaihatu (2012); Kurniawati, Suharyono, and Kusumawati (2014). Then, the items for customer loyalty were adapted from $\underline{\mathrm{Pi} \text { and }}$ Huang (2011) and Shpetim (2012). The measurement of items uses five Likert scale sizes from size 1 to 5 which means that size $1=$ strongly disagree, size $2=$ disagree, size $3=$ neutral, size $4=$ agree, and size $5=$ totally agree .

\section{RESULT AND DISCUSSION \\ Validity Test and Reliability Test}

Table 2. Measurement Model Evaluation

\begin{tabular}{|c|c|c|c|}
\hline \multicolumn{2}{|c|}{ Construct and item } & \multirow[t]{2}{*}{ Outer loading } & \multirow[t]{2}{*}{$\rho$ value } \\
\hline Valt & $(\mathrm{AVE}=0.571, \mathrm{CR}=0.888)$ & & \\
\hline V1 & I got more benefit in Maxx Coffee & 0.743 & 0.000 \\
\hline $\mathrm{V} 2$ & I got what I want in Maxx Coffee & 0.737 & 0.000 \\
\hline V3 & Price fits with the benefit I got from Maxx Coffee & 0.694 & 0.000 \\
\hline V4 & I feel happy with the benefit I got from Maxx Coffee & 0.808 & 0.000 \\
\hline V5 & I enjoyed Maxx Coffee menu & 0.797 & 0.000 \\
\hline V6 & I could easily remembering about Maxx Coffee product & 0.749 & 0.000 \\
\hline \multicolumn{4}{|c|}{ Satisfaction $(\mathrm{AVE}=0.583, \mathrm{CR}=0.874)$} \\
\hline P1 & $\begin{array}{l}\text { Compared to other coffee shop, I am satisfied with } \\
\text { Maxx Coffee service }\end{array}$ & 0.721 & 0.000 \\
\hline $\mathrm{P} 2$ & $\begin{array}{l}\text { Based on my experience, I am satisfied with Maxx } \\
\text { Coffee shop }\end{array}$ & 0.820 & 0.000 \\
\hline P3 & I am satisfied with Maxx Coffee service & 0.730 & 0.000 \\
\hline $\mathrm{P} 4$ & I am satisfied with Maxx Coffee menu variation & 0.753 & 0.000 \\
\hline P5 & I am satisfied with Maxx Coffee products & 0.787 & 0.000 \\
\hline \multicolumn{4}{|c|}{ Trust $(\mathrm{AVE}=0.650, \mathrm{CR}=0.901)$} \\
\hline $\mathrm{T} 1$ & $\begin{array}{l}\text { I believe that Maxx Coffee employees tried their best to } \\
\text { serve me }\end{array}$ & 0.586 & 0.000 \\
\hline $\mathrm{T} 2$ & Maxx Coffee shop deserved to get my trust & 0.868 & 0.000 \\
\hline T3 & Maxx Coffee shop is a reliable coffee shop & 0.896 & 0.000 \\
\hline $\mathrm{T} 4$ & Maxx Coffee shop upholds honesty & 0.831 & 0.000 \\
\hline T5 & Maxx Coffee shop upholds trustworthiness & 0.813 & 0.000 \\
\hline \multicolumn{4}{|c|}{ Brand Image $(\mathrm{AVE}=0.635, \mathrm{CR}=0.834)$} \\
\hline M1 & I think Brand 'Maxx Coffee' is easy to remembered & 0.573 & 0.000 \\
\hline M2 & $\begin{array}{l}\text { I think 'a green owl head' logo is strongly reminds me } \\
\text { about the brand image of Maxx Coffee }\end{array}$ & 0.903 & 0.000 \\
\hline M3 & $\begin{array}{l}\text { I think Maxx Coffee's brand design (form, colour, fonts, } \\
\text { and logo) is interesting }\end{array}$ & 0.873 & 0.000 \\
\hline \multicolumn{4}{|c|}{ Loyalty $(\mathrm{AVE}=0.538, \mathrm{CR}=0.850)$} \\
\hline L1 & I will visit Maxx Coffee again & 0.689 & 0.000 \\
\hline L2 & I will recommend Maxx Coffee to my friends & 0.819 & 0.000 \\
\hline L3 & $\begin{array}{l}\text { I will not shift to another coffee shop brands although } \\
\text { they offer lower price }\end{array}$ & 0.511 & 0.000 \\
\hline L4 & I prefer Maxx Coffee shops than the others & 0.794 & 0.000 \\
\hline L5 & I am proud to become Maxx Coffee customer & 0.806 & 0.000 \\
\hline
\end{tabular}

Note: AVE=average variance of extracted; $\mathrm{CR}=$ composite reliability; *=significant (on e-tailed test, $\rho<0.05)$.

Source: Data Processed

The instrument validity test was carried out using the Confirmatory Factor Analysis (CFA) approach to assess patterns of relationships between one construct and several other constructs in which each construct was built by indicators. A 
validity test is done by measuring the loading factor and Average Variance Extracted (AVE). The requirements that must be met are the cut-off values of loading factors and AVE that should be above 0.708 and 0.5 respectively (Hair et al., 2014). AVE value about more than 0.5 means $50 \%$ of the variation of indicators can be extracted by the construct. In other words, the number of variations of the extracted indicator is greater than the number of error variations. Fornell-larcker criteria identify the root value of AVE that must be above the correlation value between constructs (Hair et al. 2014). Then, the instrument reliability test is done by measuring composite reliability. The composite reliability values should be above 0.7 .

Table 2 shows the results of the validity test measurements for AVE range from 0.538 to 0.650 . The outer loading values for convergent validity ranges from 0.511 to 0.903 . Meanwhile, the composite reliability shows 0.834 to 0.901 value. Furthermore, the discriminant validity in Table 3 shows the results that meet the Fornell-Larcker criteria as the root value of AVE above the correlation value between constructs. Likewise, the measurements of AVE, the convergent validity and, composite reliability have met the criteria.

Table 3. Fornell-Larcker Ceiteria

\begin{tabular}{cccccc}
\hline & $\begin{array}{c}\text { Brand } \\
\text { Image }\end{array}$ & Trust & Satisfaction & Loyalty & Value \\
\hline Brand image & 0.797 & & & & \\
Trust & 0.448 & 0.806 & & & \\
Satisfaction & 0.515 & 0.703 & 0.763 & & \\
Loyalty & 0.465 & 0.586 & 0.719 & 0.733 & \\
Value & 0.566 & 0.620 & 0.729 & 0.672 & 0.756 \\
\hline
\end{tabular}

Source: Data Processed

\section{The Evaluation of Structural Models}

Hair et al. (2014) stated that in evaluating structural models, multicollinearity testing must be done by looking at the value of the variance inflation factor or VIF, about below 5 (Hair et al, 2014). If the VIF value is above 5 , then there is a multicollinearity problem in the model. Appendix 1 shows that the VIF value for all constructs is below the required value which is below 5, this means it meets the criteria. Then, test the hypothesis by a level of significance about 0.05 and test with a one-tailed test or tested in one direction. Appendix 2 proves that brand image and trust have no positive effect on loyalty. It can be seen that the p-value $(=0.163)$ of brand image and p-value $(=0.080)$ of trust are above the critical value of $\mathrm{p}$-value $(=0.05)$. Meanwhile, other hypotheses show satisfaction and value are also have a positive effect on loyalty with $p$ value $<0.05$ (below critical value).

Moreover, Appendix 3 shows that the total effect value of the construct of the brand image is 0.047 , the value of total effects construct of confidence is 0.0094 , the value of total effects construct of satisfaction is 0.428 and the value of 
total effects is 0.275 for the construct of loyalty. Based on the value of total effects, it can be said that the value of the total effects of the construct of satisfaction (0.428) has the greatest effect on the construct of loyalty compared to the effect of the brand image, trust, and value on the construct of loyalty. However, based on the hypothesis test in Appendix 2, it shows that the construct of trust and brand image have no positive effect on loyalty. Thus, the constructs that affect loyalty are only constructs of satisfaction and values. The evaluation $R^{2}$ in Appendix 4 informs that the construct of loyalty is explained by the construct of brand image, trust, satisfaction, and value of about $56.2 \%$, and the remaining $43.8 \%$ is explained by other constructs that are not included in this research model.

\section{Discussion}

The results of data processing through hypothesis testing $(\mathrm{H} 1)$ revealed that trust has a positive effect on loyalty, is declined. Hypothesis testing results are not fit with the results of research from Darsono (2010), Muzammil,Yunus, \&; Puspita, Yunus, \& Sulaiman (2017), Setyaningsih (2014), Soegoto (2013); and Sovani, Fauzi, \& Arifin (2016). Nevertheless, the results of this hypothesis test are in line with the results of studies from Hidayat and Firdaus (2014), and Safitri (2011). Customers believe that Maxx Coffee is a trusted, honest, trustworthy, and reliable coffee shop that serves customers well but does not guarantee customers will be loyal. However, the management of Maxx Coffee must continue to strive to increase customer confidence. Honesty and consistency factors (reliability) are important factors in customer trust.

Then, the results of testing the hypothesis $(\mathrm{H} 2)$ proved that satisfaction has a positive effect on loyalty. This result supports the results of previous studies from Bernarto and Patricia (2017) that satisfaction has a positive effect on loyalty. Furthermore, the results of this hypothesis test are also consistent with studies from Kurniawati, Suharyono, and Kusumawati (2014); Laila, Rachma, and Priyono (2017); Listyawati (2019); Muzammil,Yunus,andDarsono(2017); Setyaningsih (2014); Tjahjaningsih (2013) that satisfaction has a significant effect on increasing loyalty. When customer satisfaction increases, customers will become more loyal and trust more in the products offered by Maxx Coffee. A satisfying customer experience with Maxx Coffee shop will increase customer satisfaction and trust. If this can be maintained, then customers believe that Maxx Coffee shop is reliable, trustworthy, and honestly prioritizes customer needs. Besides that, satisfied customers will not hesitate to give testimonials to their friends that Maxx Coffee shop is worth visiting. The large number of respondents who visit Maxx Coffee shops with friends can be supporting evidence that customer satisfaction has an influence on customer loyalty and trust in Maxx Coffee shops.

The next hypothesis (H3), namely the positive effect of value on loyalty, is accepted. These results suit the research of Barnes (2000); Bernarto and Patricia (2017); Gale (2004); Soegoto (2013), that the value brings a positive effect on 
loyalty. This study says that the product benefits delivered to customers can increase the frequency of purchases. Students are having an opinion that they get benefits that suits the price they pay and get what they want. For example, the customer is being happy and enjoying the benefits so that students intend to visit again and do not hesitate to recommend Maxx Coffee to their friends.

Then, based on the results of hypothesis testing (H4) shows that brand image does not have a positive effect on loyalty. An increase or decrease in the brand image does not have an impact on customer loyalty. The results of this test are not supporting the results of research by Pramudyo (2012), but consistent with the results of research by Kaihatu (2012), Kurniawati, Suharyono, and Kusumawati (2014), Rizal, Telagawathi, Yulianthini, \& Putra (2019) who showed that the brand had no positive effect on loyalty. Students assess that the brand image of Maxx Coffee does not guarantee that students will visit again or recommend Maxx Coffee shops to their friends. This can be understood, considering that most of the respondents in this study were students with an age range of 20-22 years who were happy to try new things, including in choosing a coffee shop.

\section{CONCLUSION}

The results of the study concluded that the research conducted at Maxx Coffee showed that of the four constructs namely trust, satisfaction, and value had a positive effect on loyalty unless the construct of the brand image had no positive effect on loyalty. This study has limitations in terms of characterand the number of sampling is limited to students majoring in management, hospitality management, and medicine at UPH because of the proximity of the location of the coffee shop with their faculties building. Therefore, for further research, it is suggested that the target population can be extended to other general public to a wider location so that the management of Maxx Coffee's coffee shop can get a general picture of customers' perceptions of coffee shops and use it as input to improve and develop their services. Then, the second limitation is the sampling technique used. This research uses convenience sampling. This technique has a limitation that is not accurate in generalizing results to the population. Thus, to get better results for generalization to the population, it is recommended that future studies are better to use random sampling. The limitation of this study is that it does not include product variables from Maxx Coffee. In fact, customers visiting Maxx Coffee are basically to buy Maxx Coffee products. Therefore, the next research suggestion is to add product quality variable, so it can be known whether the quality of the product has an impact on customer loyalty or not.

\section{REFERENCES}

Anderson E., \& Weitz, B. (1989). Determinants of continuity in conventional industrial channel dyads. Market Sci. 8(4), 10-23. http://doi.org/10.1287/mksc.8.4.310. 
Barnes, G.J. (2000). Secret of Customer Relationship Management. Yogyakarta: Penerbit Andi.

Bernarto, I., \& Patricia (2017). Pengaruh perceived value, customer satisfaction dan trust terhadap customer loyalty restoran xyz di Tangerang. Journal for Business and Entrepreneur, 1(1), 36-49.

Bowden Everson, J.L.H., Dagger, T.S., \& Elliott, G. (2013). Engaging customers for loyalty in the restaurant industry: The role of satisfaction, trust, and delight. Journal of Foodservice Business Research, 16(1), 52-75. http://doi.org/10.1080/15378020.2013.761025.

Chinomona, R., \& Dubihlela, D. (2014). Does customer satisfaction lead to customer trust, loyalty and repurchase intention of local store brands? the case of gauteng province of South Africa. Mediterranean Journal of Social Sciences, 5(9), 23-32. http://doi.org/10.5901/mjss.2014.v5n9p23.

Chinomona, R., \& Sandada, M. (2013). Customer satisfaction, trust, and loyalty as predictors of customer intention to re-purchase South African retailing industry. Mediterranean Journal of Social Sciences, 4(14), 437-446. http://doi.org/10.5901/mjss.2013.v4n14p437.

Crosby, L.A, Evans, K.R.,\& Cowles, D. (1990). Relationship quality in service selling: an interpersonal influence perspective. Journal of Marketing, 54(3), 68-81. http://doi.org/10.2307/1251817.

Darsono, L. I. (2010). Hubungan perceived service quality dan loyalitas: peran trust dan satisfaction sebagai mediator. Jurnal Bisnis Perspektif, 2(1), 43-57.

Farida, N. (2010). Pengaruh ikatan hubungan, citra perusahaan, nilai pelanggan, kualitas dan kepuasan nasabah terhadap loyalitas nasabah bank pemerintah di Jawa Tengah. WACANA, 13(2), 202-213.

Gale. (2004). Customer Experience Management: A Revolutionary Approach to Connecting with Your Customer. New York: John Willey \& Sons.

Gerson, R. F. (2004). Mengukur Kepuasan Pelanggan. Jakarta: Penerbit PPM.

Ghozali, I., \& Latan, H. (2015). Partial Least Squares, Konsep, Tehnik dan Aplikasi Menggunakan Program SmartPLS 3.0. Semarang: Penerbit Undip.

Griffin, J. (2003). Customer Loyalty, Menumbuhkan \&Mempertahankan Kesetiaan Pelanggan. Jakarta: Penerbit Erlangga.

Gultom, M., \& Ngatno (2020). Pengaruh kualitas produk dan harga terhadap loyalitas pelangganmelalui kepuasan konsumen smartphone Samsung di Semarang. Jurnal Ilmu Administrasi Bisnis, 9(1), 171-172. 
BISMA (Bisnis dan Manajemen)

Volume 12Issue2, April 2020

E-ISSN 2549-7790, P-ISSN 1979-7192

Page168-185

Hair, JF., Hult, G.T.M.., Ringle, C.M.,\& Sarstedt, M. (2014). A Primer on Partial Least Squares Structural Equation Modeling (PLS-SEM). California: SAGE Publications Inc.

Hasanuddin, Maulana Rajab., Rachma, N.,\& Wahono, Budi. (2020). Pengaruh Kualitas Produk, Kualitas Pelayanan dan Kepercayaan Pelanggan terhadap Loyalitas Pelanggan. E-Jurnal Riset Manajemen, 9(11), 39-53.

He, H., Li, Y., \& Harris, L. (2012). Social identity perspective on brand loyalty. Journal of Business Research, 65(5), 648-657. http://doi.org/10.1016/j.jbusres.2011.03.007.

Herawati., W. R., Isman, \& Darham, W. (2019). Pengaruh harga dan kualitas pelayanan terhadap loyalitas melalui kepuasan konsumen. Jurnal Administrasi Sosial dan Humaniora, 3(3), 40-41.

Hidayat, D.R., \& Firdaus, M.R. (2014). Analisis pengaruh kualitas layanan, harga, kepercayaan, citra perusahaan, dan kepuasan pelanggan terhadap loyalitas pelanggan: Studi pada pelanggan Telkom Speedy di Palangka Raya. Jurnal Wawasan Manajemen, 2(3), 237-249. http://dx.doi.org/10.20527/jwm.v2i3.16.

Irawan, Handi. (2003). Membedah Strategi Kepuasan Pelanggan Merek. Jakarta: Elex Media Komputindo.

Jelemone, C. (2015). Maxx Coffee, sang burung hantu hijau penyaji kopi kopi terbaik. Retrievedfrom:https://infomoneter.com/2015/06/12/maxx-coffeesang-burung-hantu-hijau-penyaji-kopi-terbaik/

Kaihatu, T. S. (2012). Kepuasan konsumen yang dipengaruhi oleh kualitas layanan dengan brand image sebagai variabel perantara: Studi kasus pada konsumen rumah sakit swasta di kota Surabaya. Jurnal Mitra Ekonomi dan Manajemen Bisnis, 3(2), 200-210.

Keller, K. L. (1993). Conceptualizing, measuring and managing customerbased brand equality. Journal of Marketing, 57(1), 1 -22. http://doi.org/10.2307/1252054.

Kinanti, R. A. N. I., \& Fauzi, A.D.H. (2020). Pengaruh experiential marketing, citra dan customer relationship marketing terhadap loyalitas; Survey pada pelanggan rumah makan Sederhana Jatiwaringin, Jakarta Timur. Jurnal Administrasi Bisnis, 78(1), 56-65.

Kotler, P. (2000). Marketing Management. Milenium Editions, Prentice Hall Inc.

Kotler, P., \& Armstrong, G. (2008). Prinsip-Prinsip Pemasaran, jilid 1. Jakarta: Penerbit Erlangga. 
Kotler P., Hayes, T., Bloom, P.N. (2002). Marketing Professional Service. Prentice Hall International Press.

Kotler, P., \& Keller, K.L. (2012). Marketing management. England: Pearson Education Limited.

Kurniawati, D. Suharyono, \& Kusumawati, A. (2014). Pengaruh citra merek dan kualitas produk terhadap kepuasan dan loyalitas pelanggan: Studi pada pelanggan KFC cabang kawi Malang. Jurnal Administrasi Bisnis, 14(2), 1-9.

Laila, U. N., Rachma, N., \& Priyono, A. A. (2017). Pengaruh citra merek dan kualitas pelayanan terhadap loyalitas dengan kepuasan sebagai variabel intervening. Jurnal Ilmiah Riset Manajemen, 6(2), 127-150.

Lamb, C. W., Hair, J. F., \& McDaniel, C. (2005). Essentials of marketing. Australia: Thomson South-Western.

Listyawati, I. H. (2019). Pengaruh fasilitas wisata, citra destinasi dan kepuasan terhadap loyalitas wisatawan. Jurnal Bisnis Manajemen dan Akuntansi, 6(2), $36-37$.

Mandalis, A. (2005). Meraih loyalitas pelanggan. BENEFIT, 9(2), 111-119.

Menperin. (2016). Gaya Hidup Dorong Industri Kopi Tumbuh. Diambil dari https://www.kemenperin.go.id/artikel/15421/Menperin:-Gaya-HidupDorong-Industri-Kopi-Tumbuh/.

Morgan, R.M. \& Hunt, S.D (1994). The Commitment-trust theory of relationship marketing. Journal of Marketing.58(3), 20-38.

Muzammil, A., Yunus, M., \& dan Darsono, N. (2017). Pengaruh kualitas pelayanan dan citra perusahaan terhadap loyalitas pelanggan Indihome PT Telkom Indonesia di Banda Aceh dengan kepuasan dan kepercayaan pelanggan sebagai variabel mediasi. Banda Aceh.Jurnal Manajemen dan Inovasi, 8(3), 104-133.

Oliver, R.L. (1999). Whence consumer loyalty?. Journal of Marketing, 63, 33-44. doi:10.2307/1252099

Pi, W., \& Huang, H. (2011). Effects of promotion on relationship quality and customer loyalty in the airline industry: The relationship marketing approach. African Journal of Business Management.5(11), 4403-4414.

Pramudyo, A. (2012). Pengaruh citra merek terhadap loyalitas melalui kepuasan sebagai intervening.Jurnal Bisnis, Manajemen, dan Akuntansi, 1(1), 1-16.

Puspita, R., Yunus, M, \& Sulaiman. (2017). Pengaruh faktor sosial, citra merek dan kualitas produk terhadap kepercayaan merek serta dampaknya pada loyalitas pelanggan telepon selular: Studi kasus padapengguna Samsung di kota Banda Aceh.Jurnal Magister Manajemen, 1(1), 46-58. 
BISMA (Bisnis dan Manajemen)

Volume 12Issue2, April 2020

E-ISSN 2549-7790, P-ISSN 1979-7192

Page168-185

Rangkuti, F. (2004). The power of brand: Tehnik Mengelola Brand Equity dan Strategi Pengembangan Merek. Jakarta: Gramedia.

Rangkuti, F. (2006). Tehnik Mengukur dan Strategi Meningkatkan Kepuasan Pelanggan Plus Analisis Kasus PLN JP. Jakarta: Gramedia Pustaka Utama.

Rangkuti, F. (2010). Analisis SWOT Tehnik Membedah Kasus Bisnis. Jakarta: Gramedia.

Reast, D.F. (2005). Does trust and brand extension acceptance: The relationship.Journal of Product \& Brand Management, 14(1), 4-13. http://doi.org/10.1108/10610420510583707.

Rikang, R., \& Dharma, P. (2014). Orang Indonesia Makin Gemar Minum Kopi. Retrieved from:https://m.tempo.co/read/news/2014/06/30/092589168/orangindonesia-makin-gemar-minum-kopi/.

Rizal, A. S., Telagawathi, N. L. W. S., Yulianthini, N. N., \& Putra, K. E. S. (2019), Pengaruh citra merek dan harga terhadap loyalitas pelanggan sepatu merek Nike di Singaraja futsal. Jurnal Prospek, 1(2), 38-39.

Rust, R.T., Lemon, K.N. \& Zeithaml, V.A. (2004). Return on marketing: Using marketing: Using customer equity to focus marketing strategy. Journal of Marketing, 68(1), 109-127. http://doi.org/10.1509/jmkg.68.1.109.24030.

Safitri, Y. A. (2011). Kepercayaan, komitmen, komunikasi, penanganan konflik, dan perannya terhadap kepuasan terhadap loyalitas nasabah bank BCA di Surabaya.Journal of Business and Banking, 1(2), 117-130.

Scoot, Davis. (2000). Brand Asset Management Driving Profitable Growth through Your Brands. San Fransisco: Jossey Bass Publisher.

Setyaningsih, O. (2014). Pengaruh persepsi kualitas pelayanan e-commerce terhadap kepuasan pelanggan, kepercayaan dan loyalitas pada produk fashion.Jurnal Bisnis \& Manajemen, 14(2), 67-80.

Shpetim, C. (2012). Exploring the relationships among service quality, satisfation, trust and store loyalty among retail customers. Journal of Competitiveness.4(4), 16-35. http://doi.org/10.7441/joc.2012.04.02.

Simamora, B. (2002). Aura Merek, 7 Langkah Membangun Merek yang Kuat. Jakarta: Gramedia Pustaka Umum.

Soegoto, A. S. (2013). Persepsi nilai dan kepercayaan terhadap kepuasan dan dampaknya terhadap loyalitas konsumen. Jurnal EMBA, 1(3), 1271-1283.

Sovani, J. T., Fauzi, A., \& Arifin, Z. (2016). Pengaruh penerapan corporate social responsibility (CSR) terhadap citra merek, kepercayaan merek dan loyalitas merek: Survei pada masyarakat sekitar PT. Tirta Investama, desa 
Keboncandi, Kecamatan Gondang Wetan, Kabupaten Pasuruan. Jurnal Administrasi Bisnis, 10(1), 24-33.

Tjahjaningsih, E. (2013). Pengaruh citra dan promosi terhadap kepuasan pelanggan serta dampaknya terhadap loyalitas pelanggan: Studi pada pelanggan supermarket Carrefour di Semarang. Media Ekonomi dan Manajemen, 28(2), $13-27$.

Tjiptono, F. (2001). Strategi Pemasaran. Yogyakarta: Penerbit Andi.

Yang, Z., \& Peterson, R. T. (2004). Customer perceived value, satisfaction, and loyalty: The role of switching costs. Psychology \& Marketing, 21(10), 799 822. http://doi.org/10.1002/mar.20030.

Yoeti, H. Oka A. (2005). Customer Service, Cara Efektif Memuaskan Pelanggan. Jakarta: Pradnya Paramita.

Zeithaml, V.A. (1988). Consumer perceptions of price, quality, and value: a means model and synthesis of evidence. Journal of Marketing, 52(3), 2-22. http://doi.org/10.2307/1251446.

Appendix 1. Evaluasi Collinearity

\begin{tabular}{lc}
\hline & VIF \\
\hline Loyality & - \\
Brand Image & 1.531 \\
Trust & 2.091 \\
Satisfaction & 2.776 \\
Value & 2.476 \\
\hline
\end{tabular}

Source: Data Processed

Appendix 2. Hypothesis Testing

\begin{tabular}{lccl}
\hline \multicolumn{1}{c}{ Hypothesis } & $\begin{array}{c}\text { Standardized } \\
\text { Path Coefficient }\end{array}$ & p-value & Decision \\
\hline $\mathrm{H}_{1}$ : Trust positively influences loyalty & 0.094 & 0.080 & Declined \\
$\mathrm{H}_{2}$ Satisfaction positively influences & 0.428 & $0.000^{*}$ & Accepted \\
loyalty & 0.275 & $0.000^{*}$ & Accepted \\
$\mathrm{H}_{3}:$ Value positively influences loyalty & 0.047 & 0.163 & Declined \\
$\mathrm{H}_{4}$ : Brand image positively influences & & & \\
loyalty & &
\end{tabular}

Source: Data Processed

Appendix 3. Total Effects

\begin{tabular}{lc}
\hline \multicolumn{1}{c}{ Exogenous Construct } & Endogenous Loyalty Construct \\
\hline Brand image & 0.047 \\
Trust & 0.094 \\
Satisfaction & 0.428 \\
Value & 0.275 \\
\hline
\end{tabular}

Source: Data Processed 
BISMA (Bisnis dan Manajemen)

Volume 12Issue2, April 2020

E-ISSN 2549-7790, P-ISSN 1979-7192

Page 168-185

Appendix 4. Evaluation ofR ${ }^{2}$

\begin{tabular}{cc} 
Appendix 4. Evaluation ofR & \\
\hline & $\mathbf{R}^{2}$ \\
\hline Loyality & 0,562 \\
\hline Source: Data Processed
\end{tabular}

Source: Data Processed 